ORIGINAL

ISSN 0103-5150

Fisioter. Mov., Curitiba, v. 33, e003369, 2020

DOI: http://dx.doi.org/10.1590/1980-5918.032.A068

Licensed under a Creative Commons attribution

(c) (i)

\title{
Electromyographic activity of head and trunk muscles in newborns
}

\section{Atividade eletromiográfica dos músculos da cabeça e do tronco em recém-nascidos}

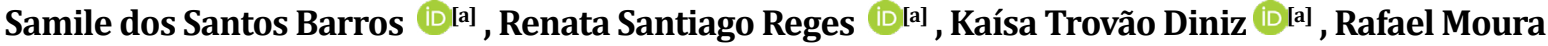 \\ Miranda [D] ${ }^{[a]}$, José Eulálio Cabral Filho (D) [b]*
}

[a] Instituto de Medicina Integral Prof. Fernando Figueira (IMIP), Recife, PE, Brazil

${ }^{[b]}$ Massachusetts Institute of Technology (MIT), Cambridge, MA, United States

\begin{abstract}
Introduction: The electric activity of muscles can be assessed using electromyography to determine their function and help identify possible delays in motor development. Objective: Determine the amplitude of the electromyographic activity of the head and trunk flexor and extensor muscles of term and preterm newborns. Method: This is a longitudinal pilot study where 20 preterm and 20 term newborns admitted to the Prof. Fernando Figueira Institute of Comprehensive Medicine were assessed. All the newborns were evaluated between 24 and 72 hours after delivery, with the premature children assessed a second time when term equivalent age was reached at 40 weeks. Data were recorded using a surface electromyograph and the electrodes were attached to the muscle bellies of the sternocleidomastoid, upper portion of the trapezius, rectus abdominis and erector spinae muscles. Results: Comparison of the electromyographic activity between the preterm newborns showed significantly higher values in all the muscles when the group reached term equivalent age. Additionally, the electromyographic activity of the term group was greater than that obtained by the preterm newborns. Conclusion: With advancing age and maturation of
\end{abstract}

*SSB: MS, e-mail: samilebarros123@outlook.com

RSR: MS, e-mail: renatasantiagor@icloud.com

KTD: PhD, e-mail: kaisa.tdz@hotmail.com

RMM: PhD, e-mail: rafael.mm@hotmail.com

JECF: PhD, e-mail: eulalio@imip.org.br 
the physiological systems, including the muscle system, preterm newborns tend to exhibit a similar muscle activation behavior to that of the term infants, resulting in better motor development.

Keywords: Muscles. Newborn. Elcetromyography.

\section{Resumo}

Introdução: Atividade elétrica dos músculos pode ser avaliada através da eletromiografia que permite verificar com detalhes a função dos músculos e com isso auxiliar na identificação de possíveis atrasos do desenvolvimento motor. Objetivo: Determinar a amplitude da atividade eletromiográfica dos músculos flexores e extensores da cabeça e do tronco de recém-nascidos a termo e pré-termo. Método: Estudo piloto, longitudinal, onde foram avaliados 20 recém-nascidos pré-termo e 20 recém-nascidos a termo admitidos no Instituto de Medicina Integral Prof. Fernando Figueira. Todos os recém-nascidos foram avaliados entre 24 e 72 horas após o nascimento, sendo as crianças prematuras avaliadas uma segunda vez quando atingiram a idade equivalente ao termo, com 40 semanas. $O$ registro foi feito através de um eletromiográfo de superfície e os eletrodos colados nos ventres musculares do esternocleidomastoideo, porção superior do músculo trapézio, no reto abdominal e eretores da espinha. Resultados: A comparação da atividade eletromiográfica do grupo recém-nascidos pré-termo mostrou valores significativamente maiores em todos os músculos quando o grupo atingiu a idade equivalente ao termo. Também foi observado que a atividade eletromiográfica do grupo recém-nascidos a termo foi maior que a encontrada no grupo recém-nascidos pré-termo. Conclusão: Os recém-nascidos pré-termo com o avançar da idade e consequentemente maturação dos sistemas fisiológicos, dentre eles o muscular, tendem a ter um comportamento da ativação muscular similar a dos recém-nascidos a termo, assim permitindo um melhor desenvolvimento motor.

Palavras-chave: Músculos. Recém-Nascido. Eletromiografia.

\section{Introduction}

The World Health Organization (WHO) defines prematurity as a child born after less than 37 weeks of pregnancy [1]. Prematurity has been linked to greater risk of motor development deficits, mainly when its behavior is compared to that of term babies [2,3]. Motor development is influenced by biological and environmental factors in terms of performance in acquired motor skills $[4,5]$.

Delayed motor development is typically associated with the presence of hypotony in preterm newborns, who exhibit extension postures in the supine position. By contrast, term babies display flexion in the same position [6], in addition to the absent or diminished primitive reflexes and reduced spontaneous movements, according to the degree of prematurity [7].

Given that the head movements of children are an important influence on subsequent motor development acquisition [5], efficient organization of shoulder, trunk and neck muscles is essential [8]. Trunk control, which stabilizes posture [9], initiates with antigravitational domination of the head, followed by control of the upper, middle and lower thoracic and lumber regions $[10,11]$.

Thus, dorsal and ventral muscle activity development is in the cephalocaudal direction, with the neck and trunk muscles activated in that order $[12,13]$. As such, specific and targeted synergy of these muscles is needed [12] to maintain body alignment and control during functional activities [14].

In this development process, an important tool in evaluating the electrical activity of newborn muscles is electromyography [15], which assesses alterations in electric power from the depolarization of muscle fibers at rest and during voluntary contractions $[16,17]$, enabling a detailed analysis of muscle function and identification of atypical motor behavior.

Although clinical assessment of the newborn development of babies is well established [18], little is known about the electromyographic activity of their 
head and trunk flexor and extensor muscles, which are vital in achieving the main motor milestones. The aim of this study was to determine the amplitude of electromyographic activity of the head and trunk flexor and extensor muscles in term and preterm infants.

\section{Method}

This is a longitudinal pilot study conducted at the Prof. Fernando Figueiro Institute of Comprehensive Medicine (IMIP), in Recife, Brazil, between March and November 2018. The project was approved by the IMIP Human Research Ethics Committee under protocol CAAE: 61377516.3.0000.5201. All participants provided written informed consent.

A total of 40 newborns of both sexes were included, 20 preterm (PTNB) and 20 term (TNB) with gestational age between 28 and 34 and 37 and 40 weeks, respectively, admitted to the Intermediate Kangaroo Care Unit (UCICA) and nurseries of the institution. Excluded were those born with 5-minute Apgar scores of less than 7, grade III or IV intracranial hemorrhage, convulsion, congenital infection, post-natal infections of the central nervous system (meningitis or encephalitis) or malfomations in the central nervous system and submitted to the kangaroo position.

Clinical data were collected from the children's medical charts, and myoelectric data obtained using a Miotool $400^{\circledR}$ electromyograph (Miotec Equipamentos Biomédicos - Brasil). All the newborns were assessed between 24 and 72 hours after delivery and the PTNB were evaluated again after reaching term equivalent age (NB-TEA) at 40 weeks. These newborns were clinically stable, tolerating food well and breathing without the help of devices or oxygen therapy.

The newborns were placed in dorsal decubitus to assess the rectus abdominis and sternocleidomastoid muscles and in lateral decubitus for the trapezius and erector spinae muscles, on a $30^{\circ}$ wedge mat, in relation to the horizontal plane. A system of channels and selfadhesive electrodes (Meditrace 100 - Infantil ${ }^{\circledR}$ ), $3 \mathrm{~cm}$ in diameter, were used to connect the newborn baby to the signal acquisition system. The recording electrodes (two on each muscle) were placed (unilaterally), in order, on each of the muscle segments: sternocleidomastoid, rectus abdominis, erector spinae and trapezius, with one muscle assessed at a time. The electrodes were placed on the central portion of the muscle belly, between the motor point and myotendinous junction, and arranged parallel to the muscle fibers, according to surface electromyography recommendations for noninvasive muscle assessment (SENIAM) [19]. In the case of the trapezius muscle, the electrode was placed on the upper portion. The reference electrode was always positioned on the right lateral malleolus.

In order to evaluate electromyographic activity, the root mean square-transformed values recorded during signal quisition were used. The signal was collected over a 60-second electromyographic reading, but only a 10 -second window was used. When active newborn movements occurred during the recording, the electromyographic signal was rejected and a new recording performed. The Myographic 2.0 program (Miotec Equipamentos Biomédicos - Brasil) was used and the signals stored in a laptop computer.

The statistical comparison of the data collected (clinical and electromyographic) occurred as follows: The Student's t-test for independent samples was applied between the TNB and PTNB groups and the Student's t-test for paired samples in the PTNB group between the first and second assessment. The alpha error to reject the null hypothesis was $\mathrm{p}<0.05$. The Sigma-Stat program, version 3.55 (Systat Software Inc - USA), was used for statistical analysis.

\section{Results}

The newborns' clinical and biological characteristics were similar in maternal age and Apgar scores. Intergroup comparison showed that the weight $(\mathrm{p}<$ $0.001)$ and gestational age $(p<0.001)$ of the preterm newborns was lower than that of the TNB (Table 1).

A comparison between the electromyographioc activity of the PTNB group showed significantly higher values in all the muscles when the group reached term equivalent age (Table 2).

TNB electromyographic activity at birth was higher than that found in the PTNB group (Table 3). However, there was no statistical significance in any of the muscles assessed when the electromyographic activity of TNB was compared with that of the newborns at term equivalent age (Table 4). 
Table 1 - Maternal and newborn characteristics at birth

\begin{tabular}{|c|c|c|c|}
\hline Variables & $\begin{array}{c}\text { PTNB } \\
(n=20)\end{array}$ & $\begin{array}{c}\text { TNB } \\
(n=20)\end{array}$ & p-value* \\
\hline Maternal age in years (mean \pm SD) & $24.25 \pm 8.61$ & $25.75 \pm 6.74$ & NS \\
\hline NB gestational age in weeks (mean \pm SD) & $31.63 \pm 2.75$ & $37.52 \pm 0.99$ & $<0.001$ \\
\hline Corrected gestational age in weeks (mean \pm SD) & $32.9 \pm 1.97$ & $39.40 \pm 1.19$ & $<0.001$ \\
\hline Birth weight $(g)$ & $1438.5 \pm 346.17$ & $3168 \pm 443.72$ & $<0.001$ \\
\hline 5-minute Apgar, Mean (min-max) & $8.64(6-10)$ & $9.35(8-10)$ & NS \\
\hline
\end{tabular}

Note: PTNB = Preterm newborn. TNB $=$ Term newborn. $S D=$ Standard deviation. NB $=$ Newborn. $G=$ gram. NS = Non-significant. ${ }^{\star} t$-test for independent samples.

Table 2 - Electromyographic activity (RMS) of the rectus abdominis, sternocleidomastoid, trapezius, and erector spinae muscles in PTNB and NB-TEA

\begin{tabular}{lccc}
\hline \multicolumn{1}{c}{ MUSCLES } & $\begin{array}{c}\text { PTNB } \\
\text { (Mean } \pm \text { SD) }\end{array}$ & $\begin{array}{c}\text { NB-TEA } \\
\text { (Mean } \pm \text { SD) }\end{array}$ & p-value* \\
Rectus abdominis & $19.73 \pm 6.08$ & $25.60 \pm 5.90$ & 0.008 \\
Sternocleidomastoid & $16.19 \pm 8.27$ & $21.61 \pm 3.13$ & 0.030 \\
Trapezius & $18.96 \pm 9.44$ & $25.19 \pm 7.73$ & 0.039 \\
Erector spinae & $12.76 \pm 5.92$ & $20.07 \pm 8.26$ & 0.008 \\
\hline
\end{tabular}

Note: PTNB $=$ Preterm newborn. NB-TEA = Newborn at term equivalent age. SD $=$ Standard deviation. RMS $=$ Root Mean Square. ${ }^{*}$ paired t-test.

Table 3 - Electromyographic activity (RMS) of rectus abdominis, sternocleidomastoid, trapezius and erector spinae muscles of PTNB and TNB

\begin{tabular}{|c|c|c|c|}
\hline MUSCLES & $\begin{array}{c}\text { PTNB } \\
(\text { Mean } \pm \text { SD })\end{array}$ & $\begin{array}{c}\text { NB-TEA } \\
(\text { Mean } \pm \text { SD })\end{array}$ & p-value* \\
\hline Rectus abdominis & $19.73 \pm 6.08$ & $29.71 \pm 10.24$ & 0.003 \\
\hline Sternocleidomastoid & $16.19 \pm 8.27$ & $23.19 \pm 5.35$ & 0.012 \\
\hline Trapezius & $18.96 \pm 9.44$ & $25.18 \pm 5.22$ & 0.025 \\
\hline Erector spinae & $12.76 \pm 5.92$ & $19.24 \pm 8.05$ & 0.014 \\
\hline
\end{tabular}

Note: PTNB $=$ Preterm newborn. TNB $=$ Term newborn. $S D=$ Standard deviation. RMS $=$ Root Mean Square. *t-test for independent samples.

Table 4 - Electromyographic activity (RMS) of the rectus abdominis, sternocleidomastoid, trapezius and erector spinae muscles of NB-TEA and TNB

\begin{tabular}{lccc}
\hline \multicolumn{1}{c}{ MUSCLES } & $\begin{array}{c}\text { NB-TEA } \\
\text { (Mean } \pm \text { SD) }\end{array}$ & $\begin{array}{c}\text { TNB } \\
\text { (Mean } \pm \text { SD) }\end{array}$ & p-value* \\
Rectus abdominis & $25.60 \pm 5.90$ & $29.71 \pm 10.24$ & 0.177 \\
Sternocleidomastoid & $21.61 \pm 3.13$ & $23.19 \pm 5.35$ & 0.348 \\
Trapezius & $25.19 \pm 7.73$ & $25.18 \pm 5.22$ & 0.998 \\
Erector spinae & $20.07 \pm 8.26$ & $19.24 \pm 8.05$ & 0.786 \\
\hline
\end{tabular}

Note: NB-TEA $=$ NB-TEA $=$ Newborn at term equivalent age. TNB $=$ Term newborn. SD $=$ Standard deviation. RMS $=$ Root Mean Square. ${ }^{*}$-test for independent samples.

\section{Discussion}

According to the results obtained, the amplitude of electromyographic activity of the axial muscles of premature newborns at birth is lower than that of term newborns, but upon reaching term equivalent age, the prematures exhibited the same electromyographic activity as that of term newborns. This result indicates that the motor activity of preterm newborns only receiving basic clinical care may develop adequately. 
The trapezius and sternocleidomastoid muscles studied here are responsible for controlling the head, which is important in postural control and precedes the subsequent functional motor skills [20,21]. Rocha et al. [22] analyzed the postural control of typical infants aged between 0 and 4 months, in supine and prone postures and found that their motor behavior in the first month of life varied considerably, but upon reaching the second month, this variability decreased, exhibiting more stable motor behavior. This may be due to acquiring better biomechanical alignment and postural stability, in addition to flexor-extensor phase transition [22]. Although we did not study motor behavior variability of term children from birth to the first month of life, preterm babies at birth exhibited a variation in their motor activity, identified by standard deviations of around 30 to $50 \%$ of mean values. However, when reaching term equivalent age, this variability became much smaller, between 14.5 and $40 \%$ in the different muscles.

These results are noteworthy because it was also observed [23] that the postural control of preterm and term babies at 15 days, 1 month, 2 months and 3 months of life exhibited a similar sequence to that of term newborns. Pretti et al. [24] assessed the development of cervical control in 18 infants applying the TIMP scale (Test of Infant Motor Performance), at 4 months of age, with gestational age corrected in the preterms. The authors found no significant intergroup differences in the development of cervical control over the months, but term babies obtained a higher score than that of preterms in items 32,35 and 36 on the TIMP scale. By contrast, the findings of the present study differed from those of Sato and Tudella [25], who assessed the level of trunk control in late preterm newborns with corrected age, and term babies between 6 and 8 months of age, where the former displayed delays in acquiring trunk control when compared to the latter.

Another study [26] investigated the development of postural adjustments during the reaching movements of premature babies. This study assessed 12 preterms between 4 and 18 months of corrected age, using electromyography in different postures: supine, sitting semi-reclined, sitting vertical with and without support. The authors found that preterm newborns reached successfully and were able to sit without support but were more delayed when compared to term babies. This is because premature babies may experience delays in motor development $[27,28]$.

Diniz KT et al. [29] used surface electromyography to investigate the effect of the kangaroo position on brachial and ischiotibial biceps (biceps femoris) in premature newborns, concluding that the kangaroo position increased short-term electromyographic activity in the group submitted to that position.

Although the evidence indicates that birth weight influences the motor behavior of infants and children [30,31], Manacero and Nunes [32] showed that premature infants divided into groups below and above $1,750 \mathrm{~g}$ exhibited a progressive sequence of motor skills and that there was no influence of birth weight on acquiring motor patterns when the percentiles were assessed by the Alberta Infant Motor Scale (AIMS). This was also observed in the present study, where there was a significant difference between the weight of PTNB and TNB, but the muscle activity of the NB-TEA was the same as that of the TNB. Similarly, Volpi et al. [33] conducted a longitudinal study of prematures free of neurosensitive sequelae with weight $<1,500 \mathrm{~g}$ and gestational age $<34$ weeks, and found that very low birth weight prematures acquired their motor skills within the limits expected for corrected ages.

The main limitation of this study was the absence of motor development assessment that correlated with the electromyographic activity of the newborns. This limitation demonstrates the need for more studies in the area.

\section{Conclusion}

The results obtained lead us to conclude that as preterm infants age and their physiological systems mature, including the muscle system, they tend to exhibit a similar muscle activation behavior to that of term newborns, thereby enabling normal motor development for the corrected age.

\section{References}

1. World Health Organization. Preterm birth. 2018 [cited 2019 Nov 19]. Available from: http://www.who.int/ mediacentre/factsheets/fs363/en/.

2. Pessoal TAO, Martins CBG, Lima FCA, Gaíva MAM. The growth and development against the prematurity and low birth weight. Av Enferm. 2015;33(3):401-11. 
3. Formiga CKMR, Vieira MEB, Linhares MBM. Developmental assessment of infants born preterm: comparison between the chronological and corrected ages. J Hum Growth Dev. 2015;25(2):230-6.

4. Formiga CKMR, Valentini NC, Amaral LEF, Pereira KRG, Saccani R, Linhares MBM. Comparison of the motor development in preterm infants from two regions of Brazil. Movimenta. 2018;11(3):400-10.

5. Fernandes PV, Gerzson LR, Almeida CS, Spessato BC. Development of the baby in handling different motor ages. R bras Ci e Mov. 2017;25(1):99-108.

6. Alves RB, Campos D. Early intervention in premature infants. Fisioter Bras. 2011;12-5.

7. Ferreira APA, Albuquerque FC, Rabelo ARM, Farias FC, Correia RCB, Gagliardo HGRG, et al. Visual behavior and the motor development of premature newborns in the first month of life. J Hum Growth Dev. 2011;11(2):335-43.

8. Heck APF, Martinello M, Medeiros DL, Coelho JJ, Ries LGK. Effect of the inclination of support in cervical and upper limb development. Fisioter Mov. 2014;27(4):601-9.

9. Shumway-Cook A, Woollacott MH. Motor control: translating research into clinical practice. 5th ed. Philadelphia: Wolters Kluwer; 2016.

10. Greco ALR, Souza C, Tudella E. Infant behavior and development indentifying the level of trunk controlo f healthy term infants aged from 6 to 9 months. Infant Behav Dev. 2018;50:207-12.

11. Rachwani J, Santamaria V, Saavedra SL, Wood S, Porter F, Woollacott MH. Segmental trunk control acquisition and reaching in typically developing infants. Exp Brain Res. 2013;228(1):131-9.

12. Van Balen LC, Dijkstra LJ, Hadders-Algra M. Development of postural adjustments during reaching in typically developing infants from 4 to 18 months. Exp Brain Res. 2012; 220(2):109-19.

13. Neves EB, Krueger E, Pol S, Oliveira MCN, Szinke AF, Rosário MO. Benefits of Intensive Neuromotor Therapy (INMT) for trunk control of children with cerebral palsy. Rev Neurocienc. 2013;21(4):549-55.

14. Ramalho VM, Kakihata AM, KanashiroMS, Oliveira LC, Branco FR, Oliveira CM, et al. Protocol of control of trunk in aquatic environment for children with cerebral palsy: randomized clinical trial. R bras ci Saude. 2019;23(1):23-32.
15. Cecco OM, Manno VM, Bommarito S. Electromyography of the masticatory muscles: analysis in the original and RMS value. Rev CEFAC. 2014;16(4):1215-21.

16. Martins CD, Furlan RMMM, Motta AR, Viana MCFB. Electromyography of muscles involved in feeding premature infants. CoDAS. 2015;27(4):372-7.

17. Mello MC, Silva LR, Bonow CA, Cezar-Vaz MR. Surface electromyography of the cervical region - contribution to muscle health. Acta Paul Enferm. 2017;30(5):512-9.

18. Behrman RE, Jenson HB, Kliegman R. Nelson Textbook of Pediatrics. 20th Ed. Amsterdam: Elsevier; 2017.

19. Hermens HJ, Freriks B, Disselhorst-Klug C, Rau G. Developmentof recommendations for SEMG sensors and sensor placementprocedures. J Electromyogr Kinesiol. 2000;10(5):361-74.

20. Saavedra SL, Van DP, Woollacott MH. Learning about gravity: segmental assessment of upright control as infants develop independent sitting. J Neurophysiol. 2012;108(8): 2215-29.

21. Wentz EE. Importance of initiating a "tummy time" intervention early in infants with down syndrome. Pediatr Phys Ther. 2017;29(1):68-75.

22. Rocha NACF, Silva FPS, Toledo AM, Tudella E. Variability in the levels of postural control in 0-4- month-old infants. Infant Behav Dev. 2009;32(4):376-80.

23. Gaetan EM, Moura RMVL. Developmental study of early posture control in preterm and full-term infants. Arq Neuropsiquiatr. 2002;60(4):954-8.

24. Pretti LC, Milan JC, Foschiani MA, Raniero EP, Pereira K. Characterization of the environmental factors and pre-term infants' cervical control. Fisioter Mov. 2010;23(2):239-50.

25. Sato NTS, Tudella E. Influence of sitting positions and level of trunk control during reaching movements in late preterm and full-term infants. Front Pediatr. 2018;6:1-11.

26. van der Fits IBM, Flikweert ER, Stremmelaar EF, Martijn A, Hadders-Algra M. Development of postural adjustments during reaching in preterm infants. Pediatr Res. 1999;46(1):1-7.

27. Fuentefria RN, Silveira RC, Procianoy RS. Motor development of preterm infants assessed by the Alberta Infant Motor Scale: systematic review article. J Pediatr (Rio J). 2017;93(4):328-42. 
28. Chiquetti EMS, Carvalho ACF, Zanella AK, Valentini NC. Risk factors and motor development of infants born small for gestational age (SGA) term and preterm. Varia Sci. 2018;4(1):110-8.

29. Diniz KT, Cabral Filho JF, Miranda RM, Lima GM, Figueredo NPS, Araújo KFN. Short-time effect of the kangaroo position on electromyographic activity of premature infants: a randomized clinical trial. J Pediatr (Rio J). 2019;S0021-7557(19)30592-3.

30. Sampaio TF, Nogueira KPA, Pontes TB, Toledo AM. Motor behavior of low birth weight and very low birth weight premature infants. Fisioter Pesqui. 2015;22(3):253-60.
31. Martins AG, Pinto PO, Saccani R. Motor development in the first year of life of premature infants according to birth weight. Sci Med. 2017;27(3):27079.

32. Manacero S, Nunes ML. Evaluation of motor performance of preterm newborns during the first months of life using the Alberta Infant Motor Scale (AIMS). J Pediatr (Rio J). 2008;84(1):53-9.

33. Volpi SC, Rugolo LMSS, Peraçoli JC, Corrente JE. Acquisition of motor abilities up to independent walking in very low birth weight preterm infants. J Pediatr (Rio J). 2010;86(2):143-8.

Received: $12 / 13 / 2019$

Recebido: 13/12/2019

Approved: 08/07/2020

Aprovado: 07/08/2020 